\title{
Comparative Analysis of Biogas Estimation Models versus In-Situ Measurement in a Landfill Site in the State of Mexico, Mexico
}

\author{
Pablo Emilio Escamilla-García ${ }^{1 *}$, María Elena Tavera-Cortés ${ }^{2}$, Francisco Pérez-Soto ${ }^{1}$ \\ ${ }^{1}$ Universidad Autónoma Chapingo, Chapingo, México \\ ${ }^{2}$ Instituto Politécnico Nacional, Mexico City, Mexico \\ Email:^peeg85@gmail.com,mtavera@ipn.mx,perezsotofco@gmail.com
}

How to cite this paper: Escamilla-García, P.E., Tavera-Cortés, M.E. and Pérez-Soto, F. (2017) Comparative Analysis of Biogas Estimation Models versus In-Situ Measurement in a Landfill Site in the State of Mexico, Mexico. Journal of Environmental Protection, 8, 1460-1473.

https://doi.org/10.4236/jep.2017.812090

Received: October 24, 2017

Accepted: November 24, 2017

Published: November 27, 2017

Copyright $\odot 2017$ by authors and Scientific Research Publishing Inc. This work is licensed under the Creative Commons Attribution International License (CC BY 4.0).

http://creativecommons.org/licenses/by/4.0/

c) (i) Open Access

\begin{abstract}
This paper shows a comparative analysis of theoretical model for biogas estimations in landfill sites in order to determine reliability, accuracy and efficiency by comparing results with actual data obtained in-situ. The model from the Environmental Protection Agency (EPA) and the Mexican model were selected to estimate biogas generation in a landfill site located in the State of Mexico, Mexico with 36 wells. Both models are based on a first order equation for degradation of organic matter assuming that the biogas generation reaches its maximum after a period of time and then biogas generation decreases exponentially while the organic fraction of waste is consumed. Measurement in-situ, using a landfill gas analyser (GA5000), resulted in values of percentage concentration of landfill gas $\left(\mathrm{CH}_{4}, \mathrm{CO}_{2}\right.$ and $\left.\mathrm{O}_{2}\right)$ with an average Frequency of $35.44 \mathrm{~Hz}(1 / \mathrm{s})$ and emissions of methane of $3355.99 \mathrm{~m}^{3} / \mathrm{hr}$ in contrast with $4885.74 \mathrm{~m}^{3} / \mathrm{hr}$ from EPA model and $6780.56 \mathrm{~m}^{3} / \mathrm{hr}$ from Mexican model. The experiment evidenced significant variations in estimations versus actual measurements. Authors discuss the aspects and parameters that cause such variations in order to provide a comprehensive analysis which will help decision makers to base waste management strategies in Mexico on reliable data.
\end{abstract}

\section{Keywords}

Biogas, Methane, Landfill Gas, Estimation Models

\section{Introduction}

Biogas is a mixture of methane $\left(\mathrm{CH}_{4}\right)(40 \%-70 \%)$, carbon dioxide $\left(\mathrm{CO}_{2}\right)$ and other gases (hydrogen, nitrogen, oxygen and hydrogen sulphide) generated by fermentation of organic materials [1]. Biogas is a flammable gaseous fuel com- 
prising $\mathrm{CH}_{4}$ primarily used as fuel. Biogas is a result of methane fermentation of different materials such as agricultural raw materials, agricultural products, food waste and liquid or solid animal feces [2]. Combustion of the biogas enables energy recovery and has been widely used in heat and power plants, among other industrial applications [3]. Biogas can be used as an energy source, and can be used in combined heat and power engines. It can be used also as a natural gas substitute by removing $\mathrm{CO}_{2}$ from $\mathrm{CH}_{4}$. The biogas is a versatile fuel that can be used for both energy generation and as feedstock for the chemical industry [4].

Biogas in generated in high volumes is mainly in landfills (also known as landfill gas). In landfill, organic matter is decomposed in absence of oxygen which results of biogas emission to the atmosphere. Municipal solid waste (MSW) landfills are the third-largest source of human-related methane emissions worldwide, accounting for approximately 15.4 percent of these emissions in 2015 [5]. At the same time, methane emissions from landfills represent a lost opportunity to capture and use a significant energy resource [6]. The control and use of this gas need to estimate, with reasonable certainty, both daily production and the cumulative production of methane $\left(\mathrm{CH}_{4}\right)$ in the long term. However, regardless the method selected to conduct estimations, methodologies should consider [7]: 1) the diagnosis is only valid at the moment of assessment and its validity decreases with time if the landfill is not monitored; 2) the methodology can only be performed for municipal solid waste landfills, regardless of the scale operation; 3) Landfill waste composition may be obtained from reported historical data, waste characterization data at the population centre or from in-situ characterization.

Large number of researches have been conducted and proved that biogas in landfills is produced by long periods of time even after waste disposal ceases, dioxins, furans and other emissions of toxic gases creates risks of explosions and fires [8] [9] [10] [11] [12]. Therefore biogas emission should be monitored in order to ensure a proper treatment; such a treatment normally involves the capture and utilization of biogas for energy production purposes. Nevertheless, economic viability of projects for constructing and operating biogas plants requires accurate information regarding composition of biogas and methane emission in the landfill [13]. The amount of biogas produced at final disposal sites is a function of the amount of waste, type and age, landfill moisture content, temperature and management practices, for this it is necessary to make the estimation of greenhouse gases, especially biogas or methane gas [14]. The estimation of biogas generated by the solid waste found in the landfills can be carried out using methodologies such as the EPA model and Mexican model which are empirical models that are based on a first order equation for degradation of organic matter. Such methodologies assume that the biogas generation reaches its maximum after a period of time before methane generation, this period is one year after the placement of the solid waste to the generation of biogas; In addition, after one year of disposing of Municipal Solid Waste (MSW), biogas generation decreases exponentially while the organic fraction of waste is consumed [15]. 
According to the above, this article considers the application of two theoretical models (EPA model and Mexican model) for the estimation of biogas in a MSW landfill in the State of Mexico, Mexico. Results are compared with accurate measurements obtained in-situ. This allowed the authors to identify degree of reliability and efficiency of theoretical models versus actual measurement in-situ by comparing variations and analysing parameters and aspect that can cause possible inconsistencies.

\section{Methodology}

The research was conducted applying different methodologies to estimate the biogas generated in "El Milagro" Landfill in the State of Mexico, Mexico. These figures were compared with real measurements obtained using a landfill gas analyzer (GA5000) in order to identify effectiveness in theoretical models.

\subsection{EPA Model}

The US Environmental Protection Agency through the Landfill Methane Outreach Program (LMOP) proposes a model which estimate landfill gas generation. This model requires data related to the average annual rate of waste disposed, the number of years the landfill has been or was open, the number of years that the landfill has been closed, the potential of waste disposed to generate methane and the rate of methane generation of the waste disposed [16]. The estimate of methane generated by the first order equation is expressed as follows [17]:

$$
\mathrm{LFG}=2 \times L o \times R \times\left(e^{-k \times C} e^{-k \times T}\right)
$$

where LFG is the total amount of landfill gas generated in the current year or in consideration $\left(\mathrm{ft}^{3}\right)$; Lo is the total methane generation potential of the waste $\left(\mathrm{ft}^{3} / \mathrm{lb}\right) ; R$ is the annual average of waste disposed during the working life (pounds); $k$ is the annual rate of methane generation (1/year); $T$ is the time since the landfill opening (years); $C$ is the time since the closure of the landfill (years) (Table 1).

\subsection{Mexican Model}

The model uses the following information to estimate biogas generation and recovery in a landfill: 1) The amount of waste deposited in the landfill annually, 2) The year of opening and closing of the site, 3) The rate of methane generation $(k), 4)$ The potential generation of methane $(L o), 5)$ The methane correction

Table 1. Parameters for $L o$ and $K$ for conventional landfills fillings (EPA Model).

\begin{tabular}{cc}
\hline Model parameters & Value \\
\hline$K$ & 0.050 per year \\
Lo & $170 \mathrm{~m}^{3} / \mathrm{ton}$ \\
\hline
\end{tabular}

Source: [17]. 
factor $(M C F), 6)$ The fire setting factor $(F), 7)$ The recovery efficiency of the capture system.

The model estimates the biogas generation rate for each year using the first degree degradation equation, which was modified by US EPA in the LandGEM Model version 3.02 in 2005.

$$
Q_{\mathrm{LFG}}=\sum_{t=1}^{n} \sum_{j=0.1}^{1} 2 k L o\left[\frac{M i}{10}\right]\left(e^{-k t_{i j}}\right)(M C F)(F)
$$

where: $Q_{\mathrm{LFG}}=$ Expected maximum biogas flow ( $\mathrm{m}^{3} /$ year); $i=1$-year time increase; $n=$ (year of calculation) - (initial year of waste disposal); $j=$ Time increment in 0.1 years; $k=$ Methane generation (1/year); $L o=$ Potential generation of methane $\left(\mathrm{m}^{3} / \mathrm{Mg}\right) ; M_{i}=$ Mass of waste disposed in year $i(\mathrm{Mg}) ; t_{i j}=$ Age of section $j$ of the mass of waste $\mathrm{M}_{\mathrm{i}}$ disposed in year $i$ (decimal years); $M C F=$ Methane correction factor; $F=$ Fire adjustment factor.

The above equation estimates the generation of biogas using amounts of waste disposed accumulated over a year. Projections for multiple years are developed by varying the projection of the annual and then iterating the equation. The total biogas generation is equal to twice the calculated methane generation. The biogas composition assumed by the model is 50 percent Methane $\left(\mathrm{CH}_{4}\right)$ and 50 percent other gases, which include carbon dioxide $\left(\mathrm{CO}_{2}\right)$ and traces of other compounds. The exponential degradation function assumes that the biogas generation is at its maximum one period before the methane generation. The model assumes a period of six months between the placement of the waste and the generation of biogas. For each unit of waste, after six months the model assumes that the biogas generation decreases exponentially as the organic fraction of the waste is consumed. The maximum generation year usually occurs in the year of closure or the following year (depending on the disposition index in the final years) (Table $2 \&$ Table 3 ).

Table 2. Methane potential generation index (Lo) (Mexican model).

\begin{tabular}{cc}
\hline Annual rainfall $(\mathrm{mm} /$ Year $)$ & Lo $\left(\mathrm{m}^{3} /\right.$ Tons $)$ \\
\hline $0-249$ & 60 \\
$250-499$ & 80 \\
$\geq 500$ & 84 \\
\hline
\end{tabular}

Source: [18].

Table 3. Methane potential generation index (K) (Mexican model).

\begin{tabular}{cc}
\hline Annual rainfall (mm/Year) & Lo $\left(\mathrm{m}^{3} /\right.$ Tons $)$ \\
\hline $0-249$ & 0.040 \\
$250-499$ & 0.050 \\
$500-999$ & 0.065 \\
$>1000$ & 0.080 \\
\hline
\end{tabular}

Source: [18]. 


\subsection{Measurement In-Situ}

Biogas emission were measured in "El Milagro" landfill located in the State of Mexico, Mexico. The landfill has 36 wells from which 20 refers to wells with flaring system whereas 16 are only used to release biogas to the atmosphere. The measurements included data from 36 wells which are in full operation currently. The average height of each well is estimated in $30 \mathrm{~m}$ with a total length of $60 \mathrm{~m}$. The general information about the landfill which was also used to feed EPA and Mexico Model algorithms, is show as follows (Table 4).

The sampling site was a landfill located in a latitude of 19.320539 and length of 98.808288 , with an extension of $255,619 \mathrm{~m}^{2}$ and located at 2260 meters above sea level with an average temperature of $16.51^{\circ} \mathrm{C}$ and $19.50^{\circ} \mathrm{C}$ and average annual rainfall of 600 to about 800 millimetres. The landfill receives a daily average of 3500 tonnes of waste coming from Mexico City and selected municipalities of the State of Mexico.

There is no active biogas extraction system at the landfill. There are several passive vent holes. In total, the landfill has 33 biogas extraction wells, of which 15 only biogas vent and 18 have burners. The wells are composed of gabion columns $(1 \mathrm{~m} \times 1 \mathrm{~m})$ with a 6 -inch diameter high-density polyethylene perforated pipe. The section above the ground level of the venting wells has a lid with a metal bell and a torch to burn the biogas. The tubes are arranged at a distance of 25 meters from each other, and each tube has 4 grooves in the perimeter arranged along the length of the tube at a distance of $25 \mathrm{~cm}$ between them. The height of the wells located in cell 1 is between 25 and 34 meters, while the tubes in cell 2 have a height of 6 meters.

\section{Results}

\subsection{Results Measuring In-Situ}

Measurements in-situ resulted in the following values (Table 5):

Table 4. Input information for models.

\begin{tabular}{cc}
\hline Opening year & 2010 \\
Projected closure year & 2037 \\
Begging of capture & 2017 \\
Average amount of waste received per year & $1,105,427$ \\
Waste-In-Place at projected closure year (tons) & $29,846,539$ \\
Average depth of landfill & $35 \mathrm{~m}$ \\
Surface in acres & $36(1$ per well) \\
$\%$ of area-waste with capture system & 85 \\
$\%$ of area-waste with intermediate coverage & 30 \\
$\%$ of area-with final coverage & 10 \\
$\%$ of area-waste with daily coverage & 60
\end{tabular}

Source: Data obtained in field work at the landfill. 
Table 6 shows the results obtained after sampling 36 well in the landfill. Concentration of methane, carbon dioxide, oxygen and frequency showed similar values per each well. The average values for the landfill are presented in Table 6 .

Table 5. Values obtained in-situ per well.

\begin{tabular}{|c|c|c|c|c|c|}
\hline Well & $\begin{array}{l}\text { Methane } \\
\left(\mathrm{CH}_{4}\right)(\%)\end{array}$ & $\begin{array}{c}\text { Carbon } \\
\text { dioxide }\left(\mathrm{CO}_{2}\right)(\%)\end{array}$ & $\begin{array}{l}\text { Oxygen } \\
\left(\mathrm{O}_{2}\right)(\%)\end{array}$ & $\begin{array}{c}\text { Frequency } \\
\mathrm{Hz}(1 / \mathrm{s})\end{array}$ & $\begin{array}{l}\text { Emissions per } \\
\text { hour of methane } \\
\left(\mathrm{m}^{3} / \mathrm{hr}\right)\end{array}$ \\
\hline 1 & 48.8 & 51 & 0.2 & 5.42 & 53.1005715 \\
\hline 2 & 50 & 50 & 0 & 5.06 & 1310.77465 \\
\hline 3 & 49.5 & 50.5 & 0 & 77.57 & $19,893.2849$ \\
\hline 4 & 49.7 & 50.3 & 0 & 113.77 & 1135.1787 \\
\hline 5 & 51.7 & 48.3 & 0 & 90.1 & $24,133.6408$ \\
\hline 6 & 49.8 & 50.2 & 0 & 0.3 & 77.4030562 \\
\hline 7 & 38.5 & 59.2 & 2.3 & 0.3 & 59.8397121 \\
\hline 8 & 51.3 & 48.6 & 0 & 76.57 & $20,350.8955$ \\
\hline 9 & 50.4 & 49.2 & 0.4 & 96.93 & $25,310.2398$ \\
\hline 10 & 50.4 & 49.6 & 0 & 79.6 & $20,785.052$ \\
\hline 11 & 51.4 & 48.2 & 0.4 & 3.48 & 35.9105825 \\
\hline 12 & 51.9 & 48.1 & 0 & 2.58 & 142.729123 \\
\hline 13 & 50.7 & 48.9 & 0.3 & 164.1 & 1670.30825 \\
\hline 14 & 51.3 & 48.7 & 0 & 4.02 & 41.4022082 \\
\hline 15 & 50.5 & 49.4 & 0.1 & 130.97 & 1327.83249 \\
\hline 16 & 50.6 & 48.5 & 0.8 & 2.32 & 23.5677753 \\
\hline 17 & 51.4 & 48.6 & 0 & 165.1 & 1703.68884 \\
\hline 18 & 52 & 48 & 0 & 72.13 & 753.007605 \\
\hline 19 & 50.8 & 49.1 & 0.1 & 20.4 & 208.052992 \\
\hline 20 & 50.2 & 49.7 & 0.1 & 0.87 & 8.76805078 \\
\hline 21 & 50.7 & 49.1 & 0.2 & 0.3 & 3.05357999 \\
\hline 22 & 49.9 & 50.1 & 0 & 22.79 & 228.310012 \\
\hline 23 & 53.3 & 46.4 & 0.3 & 0.57 & 6.09933028 \\
\hline 24 & 52.6 & 46.6 & 0.8 & 0.3 & 81.7550352 \\
\hline 25 & 44.6 & 32.9 & 5.3 & 0.3 & 2.68618673 \\
\hline 26 & 54.1 & 45.6 & 0.3 & 4.88 & 53.0025999 \\
\hline 27 & 55.4 & 40.5 & 2.3 & 0.3 & 3.33665348 \\
\hline 28 & 52.7 & 38.3 & 3.1 & 0.3 & 3.17403679 \\
\hline 29 & 54.3 & 44.9 & 0.8 & 4.68 & 51.0182749 \\
\hline 30 & 26 & 18.3 & 12.5 & 0.3 & 1.56593845 \\
\hline 31 & 56.4 & 40.2 & 1.8 & 0.3 & 3.39688188 \\
\hline 32 & 52.9 & 47.1 & 0 & 62.2 & 660.581099 \\
\hline 33 & 49.8 & 50.2 & 0.1 & 15.38 & 153.767929 \\
\hline 34 & 52.8 & 47.2 & 0.1 & 17.3 & 183.383439 \\
\hline 35 & 52.6 & 47.4 & 3.9 & 5.29 & 55.862646 \\
\hline 36 & 51.4 & 48.6 & 0 & 29.07 & 299.977193 \\
\hline
\end{tabular}

Source: Vales obtained using the GA5000. 
Table 6. Average values obtained in-situ per "El Milagro” Landfill.

\begin{tabular}{ccccc}
\hline $\mathrm{CH}_{4}(\%)$ & $\mathrm{CO}_{2}(\%)$ & $\mathrm{O}_{2}(\%)$ & $\mathrm{Hz}(1 / \mathrm{s})$ & $\mathrm{CH}_{4}$ per hour \\
\hline 50.29 & 46.88 & 1.01 & 35.44 & 3355.99 \\
\hline
\end{tabular}

Source: Self-elaborated with data from the GA5000.

\subsection{Results Using Mexican Model}

Mexican model is based on an Excel spreadsheet and is based on a first-order degradation equation. This model requires the user to feed specific data such as the year of opening, year of closure, index of annual disposition, location of the site and answer some questions regarding past and present physical conditions of the site. The model provided values for the methane $(k)$ generation index and potential methane generation $(L o)$ [19]. These values were developed using specific climate data, residue characterization and waste disposal practices from Mexico and estimated the effect of these conditions on the amounts and indices of biogas generation. Table 7 shows parameters used during modelling data.

Table 8 presents the values obtained after modelling data. It can be noted that projections models (EPA and Mexican models) estimates generation based on the waste disposed of in the landfill. The model estimates accumulation of waste increasing the amount of waste per year. Although Table 8 shows data until 2025, the model reported estimated data until 2037 that is the year projected for the landfill closure.

As reported in Table 8, the Mexican model estimates the biogas generation since the opening year of the landfill in contrast with the measurement in-situ, which provides accurate data but only in the time the biogas is measured. Estimations of biogas for following years are not provided by the equipment used in the measurement in-situ.

\subsection{Results Using EPA Model}

EPA Model is represented by the LFGcost-Web, which is a spreadsheet tool developed for EPA's Landfill Methane Outreach Program (LMOP) to estimate the costs of a landfill gas (LFG) energy projects. This tool consists of 12 required inputs to characterize the age and size of the landfill, the type of LFG energy project, and other input parameters relating to the project. Table 9 shows the main figures obtained in the EPA Model.

\section{Discussion}

Values obtained showed different levels of biogas generated. Theoretical models (EPA and Mexican model) generated estimations based on first-order degradation equations. These models resulted in marked variations as can be observed in Figure 1.

Variations on results are given by the assumptions of each model. In the EPA the landfill gas (LFG) generation estimation produced by the model is multiplied by the collection efficiency to estimate the volume of LFG that can be recovered 
Table 7. Parameters used for modelling.

\begin{tabular}{ccccc}
\hline \multicolumn{4}{c}{ Methane content in the Biogas: 50\% } \\
\hline Methane Correction Factor (MCF): 1.0 & \\
\hline Waste Category & $\begin{array}{c}\text { Fast } \\
\text { Degradation }\end{array}$ & $\begin{array}{c}\text { Moderately } \\
\text { Fast } \\
\text { Degradation }\end{array}$ & $\begin{array}{c}\text { Moderately } \\
\text { Slow } \\
\text { Degradation }\end{array}$ & $\begin{array}{c}\text { Slow } \\
\text { Degradation }\end{array}$ \\
\hline $\begin{array}{c}\mathrm{CH}_{4}(k) \text { generation } \\
\text { index: }\end{array}$ & 0.160 & 0.075 & 0.032 & 0.016 \\
$\begin{array}{c}\mathrm{CH}_{4}(\mathrm{Lo}) \text { generation } \\
\text { potential }\left(\mathrm{m}^{3} / \mathrm{Mg}\right):\end{array}$ & 69 & 138 & 214 & 202 \\
\hline
\end{tabular}

Source: Vales obtained by modelling data with the Mexican model.

Table 8. Projections of the generation and recovery of biogas in "El Milagro" Landfill.

\begin{tabular}{|c|c|c|c|c|c|c|c|c|}
\hline \multirow{3}{*}{$\begin{array}{l}\text { Year } \\
2010\end{array}$} & \multirow{3}{*}{$\begin{array}{c}\begin{array}{c}\text { Disposal } \\
\text { (Mg/year) }\end{array} \\
981,600\end{array}$} & \multirow{3}{*}{$\begin{array}{c}\begin{array}{c}\text { Accumulated } \\
\text { disposal } \\
(\mathrm{Mg})\end{array} \\
981,600\end{array}$} & \multicolumn{3}{|c|}{ Biogas generation } & \multicolumn{3}{|c|}{ Estimated biogas recovery } \\
\hline & & & \multicolumn{6}{|c|}{$\left(\mathrm{m}^{3} / \mathrm{hr}\right)\left(\right.$ feet $\left.{ }^{3} / \mathrm{min}\right)(\mathrm{mmBtu} / \mathrm{hr})\left(\mathrm{m}^{3} / \mathrm{hr}\right)\left(\right.$ feet $\left.^{3} / \mathrm{min}\right)(\mathrm{mmBtu} / \mathrm{hr})$} \\
\hline & & & 0 & 0 & 0.0 & 0 & 0 & 0.0 \\
\hline 2011 & $1,001,200$ & $1,982,800$ & 1424 & 838 & 25.4 & 0 & 0 & 0.0 \\
\hline 2012 & $1,021,200$ & $3,004,000$ & 2706 & 1593 & 48.4 & 0 & 0 & 0.0 \\
\hline 2013 & $1,041,600$ & $4,045,600$ & 3866 & 2275 & 69.1 & 0 & 0 & 0.0 \\
\hline 2014 & $1,062,400$ & $5,108,000$ & 4922 & 2897 & 88.0 & 0 & 0 & 0.0 \\
\hline 2015 & $1,083,600$ & $6,191,600$ & 5889 & 3466 & 105.2 & 0 & 0 & 0.0 \\
\hline 2016 & $1,105,427$ & $7,297,027$ & 6781 & 3991 & 121.2 & 0 & 0 & 0.0 \\
\hline 2017 & $1,127,500$ & $8,424,527$ & 7608 & 4478 & 135.9 & 4032 & 2373 & 72.0 \\
\hline 2018 & $1,150,100$ & $9,574,627$ & 8380 & 4932 & 149.7 & 4441 & 2614 & 79.4 \\
\hline 2019 & $1,173,100$ & $10,747,727$ & 9105 & 5359 & 162.7 & 4825 & 2840 & 86.2 \\
\hline 2020 & $1,196,600$ & $11,944,327$ & 9790 & 5762 & 174.9 & 5189 & 3054 & 92.7 \\
\hline 2021 & $1,220,500$ & $13,164,827$ & 10,442 & 6146 & 186.6 & 5534 & 3257 & 98.9 \\
\hline 2022 & $1,244,900$ & $14,409,727$ & 11,065 & 6513 & 197.7 & 5865 & 3452 & 104.8 \\
\hline 2023 & $1,269,800$ & $15,679,527$ & 11,665 & 6866 & 208.4 & 6182 & 3639 & 110.5 \\
\hline 2024 & $1,295,200$ & $16,974,727$ & 12,244 & 7207 & 218.8 & 6489 & 3819 & 116.0 \\
\hline 2025 & $1,321,100$ & $18,295,827$ & 12,807 & 7538 & 228.8 & 6788 & 3995 & 121.3 \\
\hline
\end{tabular}

Source: Vales obtained by modelling data with the Mexican model.

for flaring or use in an LFG energy project. However, projections are calculated based on estimates of reasonable collection efficiencies for landfills in the United States that meet US design standards and have "comprehensive" LFG collection systems [17]. Reported collection efficiencies at such landfills typically range from 50 to 95 percent, with an average of 75 percent most commonly assumed, this implies that levels of biogas estimated can significantly vary based on the multiplication of values that EPA models applies. In addition, the model typically assumes that a comprehensive system will be installed for sites without collection systems, and that future collection efficiency estimates may reflect 
Table 9. Landfill gas generation, collection, and utilization estimated for "El Milagro" landfill.

\begin{tabular}{|c|c|}
\hline \multicolumn{2}{|l|}{ Modelling Parameters for First-Order Decay Equation: } \\
\hline Methane Generation Rate, $k(1 / \mathrm{yr})$ : & 0.040 \\
\hline Methane Generation Capacity, $L_{\mathrm{o}}\left(\mathrm{ft}^{3} / \mathrm{ton}\right)$ : & 3204 \\
\hline Methane Content of LFG: & $50 \%$ \\
\hline \multicolumn{2}{|l|}{ Generated During Project Lifetime $\left(\mathrm{ft}^{3} / \mathrm{min}\right.$ LFG): } \\
\hline Minimum: & 3291 \\
\hline Annual Average: & 5663 \\
\hline Maximum: & 7659 \\
\hline \multicolumn{2}{|l|}{ Collected During Project Lifetime $\left(\mathrm{ft}^{3} / \mathrm{min}\right.$ LFG): } \\
\hline Minimum: & 2798 \\
\hline Annual Average: & 4814 \\
\hline Maximum: & 6510 \\
\hline Project Size: & Minimum \\
\hline Design Flow Rate for Project $\left(\mathrm{ft}^{3} / \mathrm{min} \mathrm{LFG}\right)$ : & 2798 \\
\hline \multicolumn{2}{|l|}{ Utilized by Project $\left(\mathrm{ft}^{3} / \mathrm{min}\right.$ LFG): } \\
\hline Annual Average: & 2601.80 \\
\hline LFG Collection Efficiency: & $85 \%$ \\
\hline
\end{tabular}

Source: Vales obtained by modelling data with the EPA model.

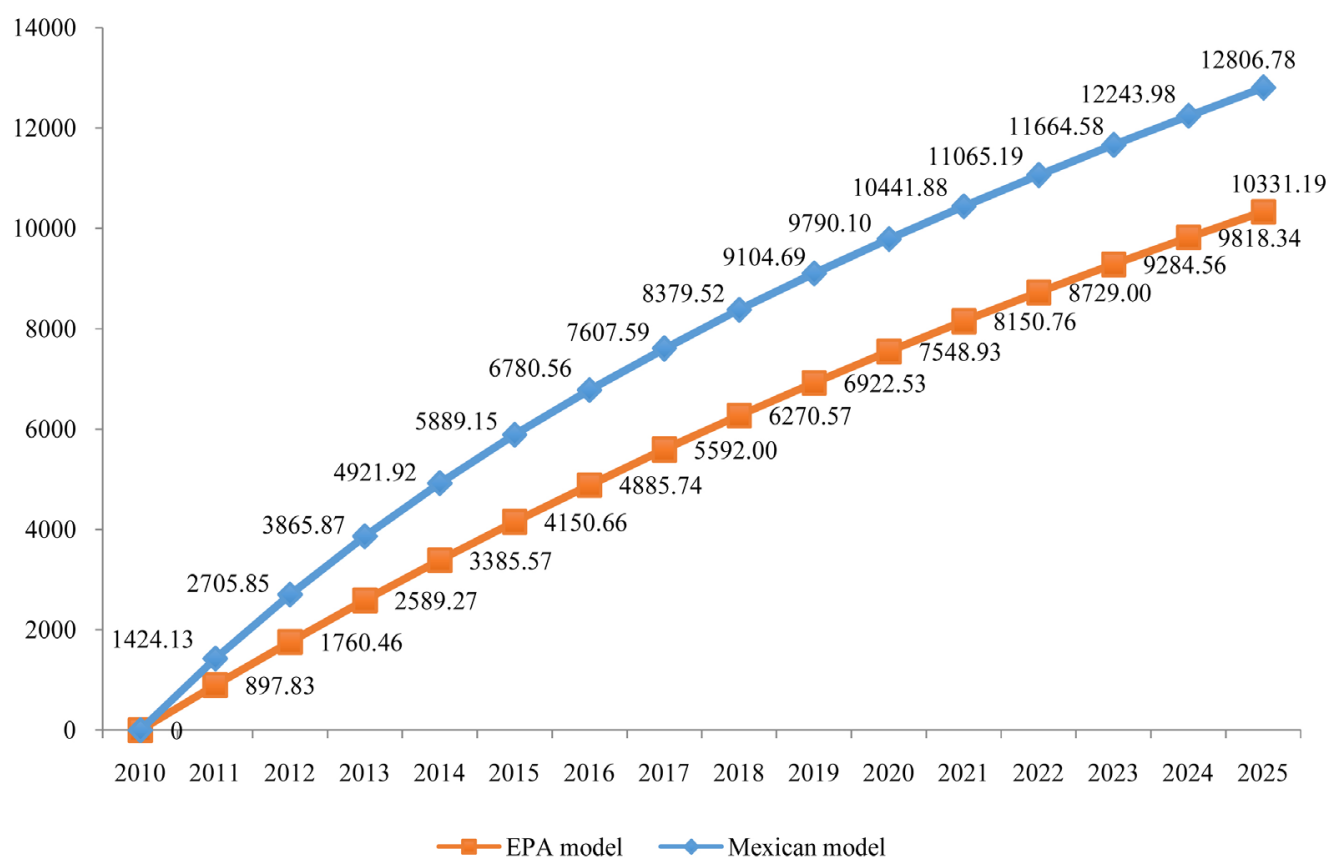

Figure 1. Estimated methane generation in projected years $\left(\mathrm{m}^{3} / \mathrm{hr}\right)$.

planned collection system enhancements [20]. This situation is barely true in most of the cases, especially in geographical regions where, given economics and social conditions, waste management policies are based on rudimentary methods and obsolete technologies, such as the case of Mexico. Therefore, different esti- 
mations models should be applied, like the Mexican model.

Figure 1 shows the estimated methane generations for projected years in the landfill "El milagro". As can be noted, there is slight variation in the values obtained in both models. For the case of the Mexican model calculate the annual disposition indexes using the information fed by the user, (this data was described in Table 4). The model automatically assigns the values of $k$ and $L o$ based on weather information and waste characterization. Values vary depending on the climate and the waste composition assumed by geographical region. The climate is categorized into five regions based on average annual precipitation and temperature. Each State in Mexico is assigned to one of the five regions. The types of waste are categorized into five distinct groups, including 4 organic groups and one inorganic group. A significant difference with the EPA model relies in that the Mexican model enables the user to feed the model with site-specific data related to waste characterization. If there is no specific information, the model will assign values depending on the selected state. Nevertheless, this element may represent an unreliable aspect that can compromise results. Statistical information related waste characterization in Mexico is inaccurate. Although in a proper waste management system, sorting facilities aim to receive MSW from transfer stations to separate recyclable materials and thus generate accurate information regarding waste characterization, the case of Mexico exhibits a deficient model. Recyclable materials are sorted and subsequently commercialized by unregulated parties. This generates unavailability of data about composition of waste. The lack of information negatively impacts on the Mexican model given that the assumptions of waste characterization are based on unreliable sources, this also applies for the alternative of feeding the model with particular information of waste.

Therefore, although values obtained in the Mexican model assume a higher generation level of landfill gas, the results cannot be considered exact and fully reliable even though the estimations consider parameters designed according to geographical characteristics in Mexico. In order to provide a proper comparison scheme to evaluate reliability of theoretical models, the measurement in-situ was conducted. The results showed the following trend:

As can be observed in Figure 2, theoretical models reported higher levels of methane emissions than actual values measured in-situ. This implies that theoretical models present limitations to provide reliable data about landfill gas generation. Nevertheless, these variations are given by different aspects. As mentioned before, the EPA model, which reported an average emission of methane of $4885.74 \mathrm{~m}^{3}$ per hour, bases estimations on characteristics (geographical aspects and composition of waste) from landfills in the United States. Composition of waste is one of the main aspects to ensure a proper estimation using theoretical models given the present of organic waste. Composition of waste is influenced by several factors including: economic activities, climate, culture, energy sources, etc. Low-income countries tend to generate a significant proportion of 


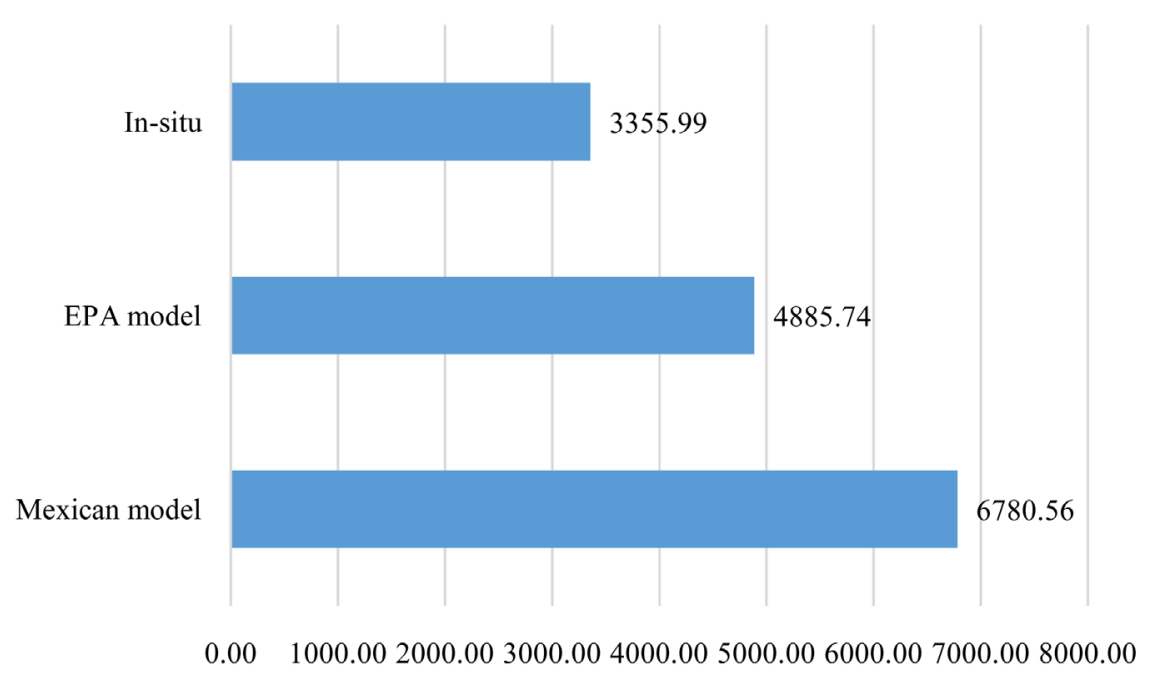

Figure 2. Emissions of methane per hour $\left(\mathrm{m}^{3} / \mathrm{hr}\right)$.

organic waste, whilst high-income countries present highest proportions of paper, plastics, and other inorganic materials [21].

Table 10 illustrates the different values of the composition of waste by income level. The table was constructed with information from the World Bank, which includes data from 105 countries classified by income and with generation rates from 2006 to 2012. The generation rate included urban areas only and in some countries the composition values were from one city only. Table 10 shows that low-income countries have an organic fraction of $64 \%$ compared to $28 \%$ in high-income countries. This shows that, as a country become wealthier, the organic fraction decreases while consumption of inorganic materials increases; however, in low and middle-income countries, there is a high percentage of organic matter ranging from $40 \%$ to $85 \%$ of the total [22]. This is an important factor due to waste composition in Mexico includes a high amount of organic waste which results in an increasing generation of biogas. Therefore, even thought the implementation of new and sustainable technologies should be apply for biogas capture and exploitation, it can be seen that in middle income countries such as Mexico, the waste management strategy must begin with actions for the reduction of organic matter disposed of landfill sites.

For the case of the Mexican model, which reported an average emission of methane of $6780.56 \mathrm{~m}^{3}$ per hour (approximately $100 \%$ more than the actual measurement in-situ), the estimation followed a similar trend; data bases of the model include a characterization of waste considering a high present of organic matter. In the case not only of the landfill "El Milagro" but also for the majority of landfills in Mexico, composition of waste is unknown and assumptions made by the Mexican model do not consider also the absence of different materials which are sorted by third parties before the disposal of waste. It must be noted that regional analysis on biogas production potential is an important reference for the construction of large and mediums biogas projects, therefore accuracy of data should be assured [23]. 
Table 10. Waste composition by income level.

\begin{tabular}{ccccccc}
\hline Income Level & $\begin{array}{c}\text { Organic } \\
(\%)\end{array}$ & Paper (\%) & $\begin{array}{c}\text { Plastic } \\
(\%)\end{array}$ & $\begin{array}{c}\text { Glass } \\
(\%)\end{array}$ & $\begin{array}{c}\text { Metal } \\
(\%)\end{array}$ & $\begin{array}{c}\text { Other } \\
(\%)\end{array}$ \\
\hline Low Income & 64 & 5 & 8 & 3 & 3 & 17 \\
$\begin{array}{c}\text { Lower Middle } \\
\text { Income }\end{array}$ & 59 & 9 & 12 & 3 & 2 & 15 \\
$\begin{array}{c}\text { Upper Middle } \\
\text { Income }\end{array}$ & 54 & 14 & 11 & 5 & 3 & 13 \\
High Income & 28 & 31 & 11 & 7 & 6 & 17 \\
\hline
\end{tabular}

Source: [22].

\section{Conclusion}

Measurement in-situ evidenced lower methane emissions than values estimated by theoretical models $(I n-s i t u=3355.99$, EPA model $=4885.74$, Mexican model $=$ 6780.56). Variations in values obtained are given by different aspects and parameters that each model assumes, also, actual characteristics of landfills in Mexico significantly differ from assumption about composition of waste. EPA model and Mexican model present similarities in the estimation method used, in both cases a first order equation evaluates pre-defined parameters however the measurement in-situ showed that the complexity of the elements necessary for the estimation of biogas generated can significantly impact on results. Theoretical models provide projections that can be used as a preliminary information to conduct a more reliable measurement. In an actual measurement in-situ using technical equipment, vales may vary from those estimated in theoretical models, however, estimation of theoretical models allow those interested in the subject to have a more precise idea of the scope and limitations of each of model and to direct their efforts and resources in further analysis, taking into consideration that theoretical models may underestimate and overestimate the projected biogas generation. If data and values expected from the theoretical models are intended to be used a base to make decisions regarding waste management strategies, including the implementation of waste-to-energy technology, or to undertake environmental programs focused on reduction of biogas emissions, therefore, theoretical models should be avoided and used only as preliminary results, in such cases, an actual measurement in-situ has to be conducted. If measurement in-situ cannot be conducted given lack of resources, therefore, special attention should be paid to the theoretical model chosen for the projections and data from the landfill should be the most reliable and accurate as possible, in order to be more precise in the prediction.

\section{References}

[1] Rajeeb, G. (2009) Biogas as a Sustainable Energy Source in Nepal: Present Status and Future Challenges. Renewable and Sustainable Energy Reviews, 13, 248-252. https://doi.org/10.1016/j.rser.2007.07.006

[2] Iglinski, B., Buczkowski, R., Iglinska, A., Cichosz, M., Piechota, G. and Kujawski, 
W. (2012) Agricultural Biogas Plants in Poland: Investment Process, Economical and Environmental Aspects, Biogas Potential. Renewable and Sustainable Energy Reviews, 16, 4890-4900. https://doi.org/10.1016/j.rser.2012.04.037

[3] Tampio, E., Ervasti, S., Paavola, T., Heaven, S., Banks, C. and Rintala, J. (2014) Anaerobic Digestion of Autoclaved and Untreated Food Waste. Waste Management, 34, 370-377. https://doi.org/10.1016/j.wasman.2013.10.024

[4] Scholz, M., Melin, T. and Wessling, M. (2012) Transforming Biogas into Bio-Methane Using Membrane Technology. Renewable and Sustainable Energy Reviews, 17, 199212. https://doi.org/10.1016/j.rser.2012.08.009

[5] EPA-Environmental Protection Agency (2016) Air Emissions from Municipal Solid Waste Landfills-Background Information for Proposed Standards and Guidelines. United States of America.

[6] Cabrera, R. and Ortiz, A. (2011) Pilot-Scale Experimental Study and Modeling of Biogas Production in Landfill. Interdisciplinary Center for Research and Studies on Environment and Development of the National Polytechnic Institute, Mexico. http://www.bvsde.paho.org/bvsacd/ciiemad/estudio.pdf.

[7] Calvo. F., Moreno, B., Zamorano, M. and Szanto, M. (2005) Environmental Diagnosis Methodology for Municipal Waste Landfills. Waste Management, 25, 768-779. https://doi.org/10.1016/j.wasman.2005.02.019

[8] Hirata, T., Hanashima, M., Matsufuji, Y., Yanase, R. and Maeno, Y. (1995) Construction of Facilities on Closed Landfills. Fifth International Landfill Symposium, Sardinia.

[9] Christensen, T.H., Cossu, R. and Stegmann, R. (1996) Landfilling of Waste: Biogas. E FN SPON Edit, London.

[10] Bramryd, T. (1997) Landfilling in the Perspective of the Global $\mathrm{CO}_{2}$ Balance. Sixth International Landfill Symposium, Sardinia.

[11] Fatta, D., Voscos, Haralambous, K.J. and Loizidou, M. (1997) An Assessment of the Effect of Landfill Leachate on Groundwater Quality. 6th International Landfill Symposium, Sardinia.

[12] Meadows, C., Franklin, D. and Campbell, P. (1997) Global Methane Emissions from Solid Waste Disposal Sites. 6 th International Landfill Symposium, Sardinia.

[13] Chakrabarty, S., Boksh, M. and Chakrabortye, A. (2013) Economic Viability of Biogas and Green Self-Employment Opportunities. Renewable and Sustainable Energy Reviews, 28, 757-766.

[14] Knox, A. (2005) An Overview of Incineration and EFW Technology as Applied to the Management of Municipal Solid Waste (MSW). Energy Subcommittee of the Ontario Environment Industry Association.

[15] Urrego-Martínez, E. and Rodríguez-Miranda, J.P. (2016) Application of EPA, Mexican and IPCC Methodologies for Biogas Estimation, Case Study of Sanitary Landfill Doña Juana, Bogotá-Colombia. Journal University and Health, 18, 338-344.

[16] Fei, X., Zekkos, D. and Raskin, L. (2016) Quantification of Parameters Influencing Methane Generation Due to Biodegradation of Municipal Solid Waste in Landfills and Laboratory Experiments. Waste Management, 55, 276-287.

[17] EPA Environmental Protection Agency (2017) LFG Energy Project Development Handbook. Landfill Methane Outreach Program. Unites States.

[18] Stege, G. and Davila, J. (1999) Manual of the Mexican Biogas Model Version 2.0. https://www.globalmethane.org/documents/events_land_20090326_landfill-26mar0 9_intro_mexico_lfg_model_alex_stege.pdf 
[19] Aguilar-Virgen, Q., Taboada-González, P. and Ojeda-Benítez, S. (2011) Mexican model for the Estimation of Biogas Generation. Academic Journal of the Faculty of Engineering, Autonomous University of Yucatan, 15, 37-45.

[20] Ayman, A., Faoura, A., Reinharta, D. and Youb, H. (2007) First-Order Kinetic Gas Generation Model Parameters for Wet Landfills. Waste Management, 27, 946-953.

[21] EPA Environmental Protection Agency (2011) Municipal Solid Waste in the United States: 2011 Facts and Figures. Office of Solid Waste. United States of America.

[22] World Bank (2012) What a Waste: A Global Review of Solid Waste Management. Urban Development Series.

[23] Chang, S., Zhao, J., Yin, X., Wu, J., Jia, Z. and Wang, L. (2011) Comprehensive Utilization of Biogas in Inner Mongolia, China. Renewable and Sustainable Energy Reviews, 15, 1442-1453. 